\title{
Multisensory Model For Home Early Literacy Stimulation: The Implementation Process
}

\author{
Lisnawati Ruhaena \\ Universitas Muhammadiyah Surakarta \\ lisnawati.ruhaena@ums.ac.id
}

\begin{abstract}
The aim of this research was to implement the multisensory model in home early literacy stimulation and to obtain feedback from the application to improve the model for the next implementation. The method used was action research as the researcher intended to discover the process of how the multisensory model was applied. The implementation was categorized into four stages, and was followed by 56 dyads motherchild. All of them lived in Surakarta City. The qualitative data was collected using open-ended questionnaires, diaries, observation, and interviews. Content analysis was applied to the data. The results showed the steps of implementation and process of early literacy stimulation for each step. The processes was started by need assessment and followed by three different cycles; shared book reading, alphabet flashcard game, and activity book. Moreover, this research found that multisensory model brought up positive atmosphere to attract children interest and to encourage mother engagement in literacy activities. The benefit of affective interaction also was obtained. Therefore, it is highly recommended to apply multisensory model in a larger community.
\end{abstract}

Keywords: multisensory, early literacy, home stimulation, community development

\section{INTRODUCTION}

The literacy skill of Indonesian children are lower than the literacy ability of children from other countries. This can be seen from the results of the Progress in International Reading Literacy Study (PIRLS), an international study of children's reading in the world in 2011 sponsored by The International Association for the Evaluation Achievement. The results of the study revealed that the ability of fourth grade students of primary school in Indonesia was ranked 41 out of 50 countries in the world. In PIRLS 2011, students at the fourth and sixth grade had higher reading achievement if their parents like reading, and they were often engaged in early literacy activities with their children, and have more home resources for learning. It means that early literacy activities can determine early literacy skill and reading achievement.

According to (Weigel, Martin, \& Bennett, 2006), home and family as well as school are main factors to support early literacy development. Rich home environment in literacy stimulation has been shown to increase the literacy skill of children (S. R. Burgess, 2010; Melhuish et al., 2008; Park, 2008). The effect of the home environments are stronger than the pre-school program (Melchish, Sylva, Samons, Sirajlachford, \& Taggart, 2008). A responsive and supportive home environment is the strongest predictor of language skills and children's literacy (Roberts, Jurgens, \& Burchinal, 2005). Regular home environments are positively and significantly correlated with expressive language skills, reading abilities and phonological skills in families whose mothers have above average reading abilities (Johnson, Martin, Brooks-Gunn, \& Petrill, 2008). In addition, all forms of text that exist around the house can be used as media such as logos, labels, and names of streets or stores (M.M. Neumann, Hood, \& Ford, 2013; M.M. Neumann, Hood, Ford, \& Neumann, 2012). Touch screen of tablet now enables children to do literacy activities (Michelle M Neumann, 2014).

Literacy activities at home are predictor of expressive and receptive language development (Deckner, Adamson, \&
Bakeman, 2006), and the influence is greater than parental education and economic status (Melhuish et al., 2008). Children activities with parents in the form of playing and learning alphabet, letter sounds, and writing letters can predict phonological knowledge and sensitivity of letters (Evans, Shaw, \& Bell, 2000).

Share book reading of parents with their children are important to improve the ability of spoken language, phonological sensitivity, alphabetical knowledge, vocabulary, and children understanding (Aram, Fine, \& Ziv, 2013; S. Burgess, 2002; Raikes et al., 2006). The frequency of reading a book, especially every day, and the exposure of children with books increase their initial literacy skills (Raikes et al., 2006; Sénéchal \& LeFevre, 2002; Stephenson, Parrila, Georgiou, \& Kirby, 2008)

However, parents reading books encourage children to actively engage in literacy activities so that the children are more focused on texts (Evans et al., 2000; Levy, Gong, Hessels, Evans, \& Jared, 2006). The quality of affective interaction while reading the book and the explanation of the object (metalingual utterances) become a predictor for the children motivation in reading (Deckner et al., 2006). Another form of parental involvement is teaching children about names and sounds of letters and teaching how to read and write words (Sénéchal \& LeFevre, 2002; Stephenson et al., 2008). In this case, the function of family is as an educator that improves the ability of children's literacy (Bennett, Weigel, \& Martin, 2002). The activity of reading a book is also an opportunity to transfer an intergenerational culture (Kenner, Ruby, Jessel, Gregory, \& Arju, 2007).

To sum up, the role of home environments, parents' involvement in literacy activities and parents and children interaction during literacy activities contribute significantly to develop early literacy skills of children. It is no doubt that literacy activities have to be run in every family for every day basis. Early literacy activities take place at home and are created by parents, especially by mothers as a very significant person for pre-school children. However, creating literacy activities is not easy. A lot of mothers have lack of skill to create literacy activities that attract children interest. In 
addition, pre-school children have low literacy interest (Ruhaena, 2014). In order to solve this problem, mothers have to be empowered in doing literacy activities with their children at home. Mothers then can be more confident and consistent in stimulating early literacy skill.

Multisensory model is an alternative solution to stimulate early literacy when children are playing at home. It is a systematic and interesting approach to stimulate early literacy skills of pre-school children using meaningful events of literacy and contextual play to ensure optimum function of their visual, auditory, and kinesthetic skill. In multisensory model, mothers are supported by knowledge and skill of enjoyable literacy stimulation. There is also literacy media provided to attract children interest in literacy. Therefore, mother as a significant person for children would be able to create varieties of literacy activities using varieties of literacy media.

Multisensory model has been validated as an intervention to support mothers with the skill and media of literacy activities. It then enables the mothers to develop early literacy skill of their children. However the model has not been implemented yet to solve the problem. In this research, the model is implemented to empower the mothers in literacy activities and look for the feedback in the process of implementation. So, the research questions to be answered are: In what way was multisensory model implemented step by step? In what way did each step stimulate children's early literacy skill? What kinds of findings that enable improvement of multisensory model for the next to be applied?

\section{METHOD}

\section{Design}

This study used action research (McNiff, 2002) to allow the multisensory model to be implemented in a community step by step so that the feedback from the prior step enables improvement in the next step of implementation. Prior to the cycles, need assessment was done to understand clearer about the community.

\section{Stage of study}

Before the implementation, the need assessment was carried out in first stage. The implementation was divided into three cycles according to the kind of literacy activities. Each cycle was run through four steps: planning, acting, observing, and reflecting, as represented in figure 1. Planning was intended to prepare the literacy program, acting was intended to do the literacy program, observing was carried out to understand how the program was running, and reflection was aimed to get insight of the program in order to plan the next cycles.

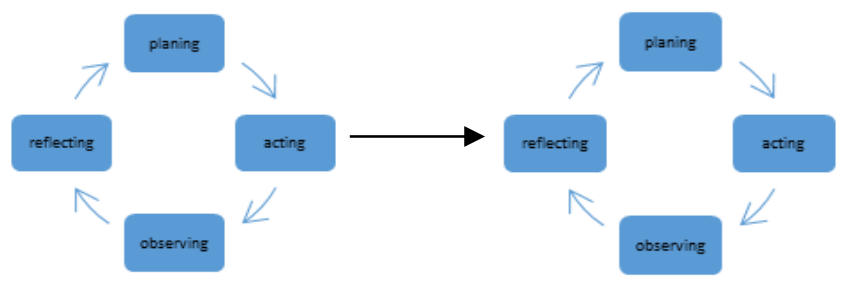

Figure 1. Stage of Study

\section{Context and Participants}

This research was conducted in a rural city, Surakarta, Central Java, Indonesia. The literacy ambassadors were recruited from undergraduate students of Psychology
Department in Universitas Muhammadiyah Surakarta. They were selected with certain requirements: had learnt observation and interview technique of data gathering, had willingness to help a community, and had filled in the inform consent. While the mothers were selected by a literacy ambassador with the criteria; have a pre-school child from 3 to 5 years old, live in Surakarta, are committed to join the program and fill in the inform consent. The participants were 56 dyads mother-child. The children were above 3 and below 5 years old.

\section{Procedure}

Model multisensory is implemented to the community as a literacy program. The program aimed to exposure early literacy activities to the family, especially mothers of pre-school children. At the beginning, the program was held in multifunction room in Kelurahan Jajar. But the participant's attendance tent to decrease, from 22 participants in first meeting to only 6 participants in forth meeting. Therefore the researcher changed the way of literacy program was held, from gathering participants in one place into visiting participants at their own home. So, the mothers were helped individually by literacy ambassadors. Volunteers consisting of 21 undergraduate students were recruited to join the research as literacy ambassadors. Literacy ambassadors were asked to find 2 or 3 dyads mother-child around their neighborhoods. Mothers than were asked to fill in the inform consent as they committed to join the literacy program. Literacy ambassadors were trained to help mothers when they do home visit. The two days training (14 hours) enable them to do promoting, demonstrating and counseling. They promoted early literacy stimulation, demonstrated literacy activities, and counseled mother who were not confident in literacy activities. Each literacy ambassador helped 2 or 3 dyads mother-child.

Shared book reading is planned to be the first literacy activity that is introduced to the mothers by literacy ambassadors. The literacy kits for shared book reading were prepared. The researcher also explains the ambassadors how to collect the data about shared book reading activity by using questionnaires and observation. Literacy ambassadors did home visit and empowered the mothers to do shared reading book with their children. Then, each ambassador brought them first literacy kits consisting of a story book, a hand puppet, a drawing book, and color pens. They demonstrated how mother can involve children to shared book reading activities. Besides shared book reading activities, the other literacy activities were alphabet flashcard game and book activity. The literacy ambassadors provided mother with alphabet flashcard and an activity book to facilitate the children. Then, the literacy ambassador also shared the knowledge and demonstrated how to play with flashcard and activity book.

\section{Data Collection}

In order to understand how the literacy program was running, the data were collected. The ambassadors took observation notes to get the description about mothers and their children interaction during shared book reading and the setting of home environment. An interview was carried out to ask mothers' opinions about shared book reading, diary and openended questionnaires to discovered family routines of literacy activities. The data were collected by using literacy ambassadors from the mothers using interviews, open ended questionnaires, diaries, and also observation. The interview technique was mostly in the form of probing data about mothers' opinions or understanding of literacy activities. Open-ended questionnaires and diaries gathered data about daily activities and family routines in literacy activities. While observation focused on the interaction between the mothersand children during literacy activities. 


\section{DATA ANALYSIS}

The content of the data was analyzed to find the theme or key concept from the qualitative data. The theme then was categorized and counted in frequencies. The data were collected with three different techniques to allow validity by triangulation. Moreover, the content analyzed was carried out by three analysts to make sure that the interpretation was correct.

\section{RESULTS}

\section{Need assessment}

In this step, according to the open-ended questionnaires, observation, and interviews in the very beginning, there were some conditions to be considered in doing literacy program as listed in table 1. Need assessment discovered that literacy activities were not yet preferred as favorite activities or even as daily activities for most children. Most mothers did interactive conversations during playing with their children. About half of mothers preferred to stimulate literacy by doing shared book reading. Mostly, children had favorite literacy media such as paper and pencil, coloring book, story book, alphabet puzzle, and alphabet fridge. So, it was found that children needed more frequent exposure to literacy activities. A mother could become a good teacher for their children in promoting literacy activities especially shared book reading. Conversation between mother and children could be beneficial for encouraging children interest in literacy activity.

Table 1. Need Assessment Analyzed

\begin{tabular}{|c|c|c|}
\hline Questionnaire & Observation & Interview \\
\hline $\begin{array}{l}12 \% \text { children preferred literacy } \\
\text { activity (coloring, drawing, } \\
\text { storytelling) in daily activity. } \\
\text { Most of the children }(87 \%) \text { prefer } \\
\text { playing motor cross. } \\
34 \% \text { Mother encouraged their } \\
\text { children in literacy activity, but } \\
\text { most of the mothers encouraged } \\
\text { their children (55\%) to play } \\
\text { motor cross. } \\
21 \% \text { Children preferred literacy } \\
\text { activities as a favorite activity } \\
51 \% \text { mothers did shared book } \\
\text { reading with their children } \\
68 \% \text { Mothers did interactive } \\
\text { conversation during playing with } \\
\text { their children. } \\
78 \% \text { Children had favorite } \\
\text { literacy media (book, puzzle, } \\
\text { letter fridge, poster) }\end{array}$ & $\begin{array}{l}\text { At home, the } \\
\text { majority of } \\
\text { children have } \\
\text { only a limited } \\
\text { collection of } \\
\text { story books. } \\
\text { Rarely found } \\
\text { letter poster or } \\
\text { children's } \\
\text { drawing were } \\
\text { displayed. }\end{array}$ & $\begin{array}{l}\text { Most } \\
\text { mothers } \\
\text { were } \\
\text { interested in } \\
\text { literacy } \\
\text { program and } \\
\text { decided to } \\
\text { join in order } \\
\text { to be able to } \\
\text { be better in } \\
\text { developing } \\
\text { their } \\
\text { children's } \\
\text { skill in } \\
\text { literacy. }\end{array}$ \\
\hline
\end{tabular}

Other than shared book reading, playing with letters and doing book activities would suit the children's need. Therefore, shared book reading, playing alphabet flashcard, and doing book activity were preferred for the steps in literacy program as listed in table 2. It was necessary to fulfill children's need in moving, playing while they are learning to recognize, memorize, and understand. They were more active to construct the knowledge when playing and manipulating concrete objects. Children then were able to internalize meaningful context or situation to encourage their interest in literacy activities.
Table 2. Step by Step of Multisensory Model Implementing

\begin{tabular}{|c|c|c|}
\hline Cycles & Stages & Activities \\
\hline \multirow[t]{4}{*}{$\begin{array}{l}\text { Cycle } 1 \text { Story } \\
\text { book reading }\end{array}$} & Planning & $\begin{array}{ll}\text { - } & \text { Preparing shared book } \\
& \text { reading kit } \\
- & \text { Preparing manual activity } \\
- & \text { Preparing literacy } \\
& \text { ambassador training }\end{array}$ \\
\hline & Acting & $\begin{array}{ll}\text { - } & \text { Literacy ambassador training } \\
\text { - } & \text { Story book reading (Home } \\
\text { visit) }\end{array}$ \\
\hline & Observing & $\begin{array}{ll}\text { - } & \text { Observing shared book } \\
\text { activities and home setting } \\
\text { - Collecting data (observation, } \\
\text { interview, diary, open-ended } \\
\text { questionnaire) }\end{array}$ \\
\hline & Reflecting & $\begin{array}{ll}\text { - } & \text { Identifying the feedback of } \\
\text { story book reading } \\
\text { - } \quad \text { Planning the next step of } \\
\text { implementation }\end{array}$ \\
\hline \multirow[t]{4}{*}{$\begin{array}{l}\text { Cycle } 2 \\
\text { Alphabet } \\
\text { flashcard game }\end{array}$} & Planning & $\begin{array}{ll}\text { - } & \text { Preparing manual of playing } \\
\text { with flashcard } \\
\text { - } \quad \text { Preparing a playing kit }\end{array}$ \\
\hline & Acting & $\begin{array}{ll}\text { - } & \text { Literacy ambassador training } \\
\text { - } & \text { Playing flashcard game } \\
\text { (Home visit) }\end{array}$ \\
\hline & Observing & $\begin{array}{ll}- & \text { Observing flashcard game } \\
\text { - } & \text { Collecting data (observation, } \\
\text { interview, diary) }\end{array}$ \\
\hline & Reflecting & $\begin{array}{l}\text { - } \quad \begin{array}{l}\text { Identifying the feedback of } \\
\text { alphabet flashcard game }\end{array} \\
\text { - } \quad \text { Planning the nexstep of } \\
\text { implementation }\end{array}$ \\
\hline \multirow[t]{4}{*}{$\begin{array}{l}\text { Cycle 3Activity } \\
\text { book }\end{array}$} & Planning & $\begin{array}{ll}- & \text { Preparing activity book } \\
\text { - } & \text { Preparing manual activity } \\
- & \text { Preparing literacy } \\
& \text { ambassador training } \\
\end{array}$ \\
\hline & Acting & $\begin{array}{l}\text { Literacy Ambassador } \\
\text { training } \\
\text { Book Activity (Home visit) }\end{array}$ \\
\hline & Observing & $\begin{array}{ll}\text { - } & \begin{array}{l}\text { Observing book activity } \\
\text { (home visit) }\end{array} \\
\text { - } \quad \text { Collecting data (observation, } \\
\text { interview, diary) }\end{array}$ \\
\hline & Reflecting & $\begin{array}{ll}\text { - } & \text { Identifying the feedback of } \\
\text { activity book } \\
\text { - } \quad \text { Evaluating all steps of } \\
\text { implementation }\end{array}$ \\
\hline
\end{tabular}

Table 3. Cycle 1, Shared Book Reading

\begin{tabular}{|c|c|c|}
\hline Diary & Observation & Interview \\
\hline $\begin{array}{l}\text { After joining } \\
\text { the literacy } \\
\text { program, } \\
\text { Mothers and } \\
\text { children did } \\
\text { literacy } \\
\text { activities about } \\
15 \text { minutes at } \\
\text { noon or } \\
\text { afternoon. } \\
48 \% \text { of them } \\
\text { did it everyday } \\
\text { for one month, } \\
\text { and } 73 \% \text { did } \\
\text { once to third in } \\
\text { a week for } \\
\text { around one } \\
\text { month. }\end{array}$ & $\begin{array}{l}\text { During shared book } \\
\text { reading, most of } \\
\text { mothers did well in } \\
\text { literacy stimulation, } \\
\text { specifically } \\
\text { - 93\% are able to } \\
\text { guide and engage } \\
\text { children in } \\
\text { dialogue } \\
\text { - } 80 \% \text { are able to } \\
\text { attract children } \\
\text { interest and } \\
\text { engagement } \\
\text { - 78\% are interactive } \\
\text { and communicative } \\
\text { - 78\% of mothers } \\
\text { did metalingual } \\
\text { utterances } \\
\text { The mothers were able } \\
\text { to create positive } \\
\text { experiences, so so } \\
\text { children tend to be } \\
\text { responsive }(82 \%) \\
\text { while doing shared } \\
\text { book reading. Then, } \\
71 \% \text { of the mothers } \\
\text { were happy and } 61 \% \text { of } \\
\text { the children were also } \\
\text { happy. }\end{array}$ & $\begin{array}{l}\text { One week after the } \\
\text { mothers and children } \\
\text { had a kit of shared } \\
\text { book reading, } \\
-\quad 95 \% \text { enjoyed } \\
\text { one or more of } \\
\text { the media } \\
\text { literacy in a kit } \\
91 \% \text { did } \\
\text { literacy } \\
\text { activities such } \\
\text { as storytelling, } \\
\text { shared book } \\
\text { reading, } \\
\text { coloring, and } \\
\text { drawing } \\
\text { During shared book } \\
\text { reading, children } \\
\text { - } 86 \% \text { responded } \\
\text { enthusiastically, } \\
71 \% \text { enjoyed } \\
\text { the story and } \\
\text { asked questions }\end{array}$ \\
\hline
\end{tabular}


In table 1, shared book reading allowed the mothers to interact with their children to stimulate and develop children in early literacy skill. The stimulation processes took place through literacy activities which were done routinely every day although in a relatively short time, about 15 minutes. This routine is more effective in developing children's literacy skills. Moreover, the mothers interact with the children when reading a story book, supported children to focus on their attention and interest into the contents of the book. Children also were stimulated by the mothers to engage actively, interactively, and communicatively while discussing the contents of the book. In addition to story books, namely hand puppet, drawing books and markers support the literacy activities to be more fun for the mothers and children. It was found that shared book reading was enjoyable for both the mothers and children. However, other literacy activities were necessary to suit children's needs for playing and moving.

Table 4. Cycle 2, Alphabet Flashcard Game

\begin{tabular}{|c|c|c|}
\hline Diary & Observation & Interview \\
\hline $55 \%$ of the children & Alphabet flashcard & mothers \\
\hline played alphabet & games were played & attracted \\
\hline flashcard & after the mothers & children to play \\
\hline They found letters & persuaded and gave & game by inviting \\
\hline while running for & examples to attract & and showing them \\
\hline treasure hunt & children's & how to play. Then, \\
\hline naming & involvement. & mothers \\
\hline while composing & Alphabet & accompanied the \\
\hline words or playing & flashcard enabled the & children. \\
\hline car & $\begin{array}{l}\text { children to play } \\
\text { enthusiastically }\end{array}$ & \\
\hline
\end{tabular}

In table 2, an alphabet flashcard game was intended to address children' needs in moving while learning. Therefore, the children found it interesting to learn letters while playing treasure hunt or playing card. However, first the mothers had to show how to play before the children were involved. Mostly, the children enjoyed the game after first trying. Therefore, literacy activities could be adjusted to the need of the children. The mothers could create many different ways of playing to introduce letters and had insight about children's enjoyable learning. The children were interested in letters and could be introduced an activity book

Table 5. Cycle 3, Activity Book

\begin{tabular}{|c|c|c|}
\hline Diary & Observation & Interview \\
\hline $\begin{array}{l}\text { A number of } \\
\text { children did: } \\
-\quad \text { Coloring } \\
\quad 33 \\
-\quad \text { Drawing } \\
\quad 22 \\
\text { - Writing letter } \\
\quad 16 \\
\text { - Cutting } \\
\quad 4 \\
\text { There were } 77 \% \text { of } \\
\text { the mothers who } \\
\text { perceived that } \\
\text { children were bored } \\
\text { and had less } \\
\text { concentration, as the } \\
\text { obstacle. }\end{array}$ & $\begin{array}{l}\text { At the beginning, } \\
\text { the mothers } \\
\text { frequently asked } \\
\text { the children to do } \\
\text { the activity book. } \\
\text { Then the mothers } \\
\text { accompanied and } \\
\text { showed how to do } \\
\text { activity book. } \\
\text { Finally, the } \\
\text { children enjoyed } \\
\text { coloring, drawing, } \\
\text { and writing letters. }\end{array}$ & $\begin{array}{l}\text { The mothers found } \\
\text { the benefits of } \\
\text { activity book were: } \\
\text { - Increasing } \\
\text { children's } \\
\text { knowledge } \\
\text { - Improving fine } \\
\text { motor } \\
\text { coordination } \\
\text { Improving } \\
\text { mother-child } \\
\text { bounding } \\
\text { Focusing } \\
\text { children's } \\
\text { concentration } \\
\text { The mothers stated } \\
\text { they needed } \\
\text { interesting literacy } \\
\text { media to attract the } \\
\text { children. } \\
\text { Patience } \\
\text { diligence also were } \\
\text { necessary to develop } \\
\text { children's interest. } \\
\text { Creativity and } \\
\text { leisure time to do } \\
\text { literacy game with } \\
\text { the children were } \\
\text { important too. }\end{array}$ \\
\hline
\end{tabular}

Similar with alphabet game, in table 3 activity book, the mothers had to ask the children at the beginning. But, after the children involved, they enjoyed coloring besides drawing and writing letter. The mothers experienced the benefits of activity book, and needed more media other than their patience, diligence, and creativity. The mothers' leisure time could be more meaningful when stimulating children's literacy skill.

\section{DISCUSSION}

The main purpose of this study was to find answers of three questions: a) in what way was multisensory model implemented step by step? In what way did each step stimulate children in early literacy skill? What kind of findings that enables improvement of multisensory model for the next to be applied? To address these questions, the data were analyzed and concluded. Model multisensory were implemented through four steps which were need assessment, shared book reading, alphabet flashcard game, and activity book. Need assessment gave a clear picture of the condition and guided the planning of literacy program to meet the needs of the mothers and their children. It was discovered that children need exposure to text, letter, and related book activities, so shared book reading was preferred. Children also loved to play and move, and then alphabet flashcard game was chosen. Children loved coloring, so book activity was provided.

Each step in literacy program was designed as playing activities to suit the multisensory approach. It was supported by the previous study of (Brooker, 2011) that literacy activities have to be fun played. Such a play can be done as a conversation to give verbal scaffolding, letter, and word game (Evans et al., 2000; Roskos, Christie, Widman, \& Holding, 2010; Stephenson et al., 2008), and drawing, writing (Fisher, 2010). Moreover, the shared book reading confirmed to develop early literacy of children (Aram et al., 2013). The result showed that shared book reading allowed the mothers to interact with their children in such a stimulating way. This interaction enables the mothers to give scaffolding conversation to their children and supporting them to be actively involved. In addition, shared book reading which is done regularly, in daily basis (even for about 15 minutes) could build family literacy routines. Family literacy routines are able to improve early literacy skill consistently and steadily. The media (book, hand puppet, marker, drawing book) used in literacy activities attracted children's interest and help them focus on their attention. In the second step, the children played alphabet flashcard game to allow them moving while learning. They were interested in playing treasure hunt or playing cards when the letters are introduced. The way the mothers encouraged the children to take a part in alphabet flashcard game became a significant skill that determined children's involvement. In the last step, activity book, the children were trained a basic skill of fine motor coordination for writing. While coloring an activity book, the children also increased a sense of motor control and creativity. Mother's patience and diligence were necessary to guide children in doing activity book.

There were several findings which were very important for the improvement in the next implementation. The findings were the commitment of the participants, the literacy kit and the literacy ambassador. Mothers as the participants who had commitment were fully cooperative and faced the challenges. While the lack commitment mothers, had difficulties in making appointments with literacy ambassadors and doing literacy stimulation at home with their children. Then, it was very important to approach the mothers properly to gain their 
commitment. The other finding, about the literacy kit, it was recommended to write the story book in order to suit the specific need of the program. The supply of the suitable books at the store was limited. The last finding about literacy ambassador, the main factor that made them do their job successfully was their interest to help and share their willingness to help and their motivation to face challenges or difficult situations.

\section{CONCLUSION AND RECOMMENDATION}

Multisensory model is a systematic approach to stimulate early literacy skills of pre-school children using meaningful literacy activities and contextual playing to ensure optimum function of their visual, auditory, and kinesthetic. It was validated in an earlier study and implemented in this research in four stages: need assessment, shared book reading, alphabet flashcard game, and activity book. The literacy activities enable the mothers to interact with the children and allow them to be actively involved in contextual reading and writing. It attracted the children to learn early literacy skills in an enjoyable way. Therefore, it is highly recommended to apply multisensory model in the larger community. However, it is necessary to improve the commitment of the mothers, the motive for help and share of literacy ambassador and to write the story book for the next implementation.

\section{REFERENCES}

Aram, D., Fine, Y., \& Ziv, M. (2013). Enhancing parent-child shared book reading interactions: Promoting references to the book's plot and socio-cognitive themes. Early Childhood Research Quarterly, 28(1), 111-122. doi: 10.1016/j.ecresq.2012.03.005

Bennett, K. K., Weigel, D. J., \& Martin, S. S. (2002). Children's acquisition of early literacy skills: examining family contributions. Early Childhood Research Quarterly, 17(3), 295-317. doi: 10.1016/s0885-2006(02)00166-7

Brooker, L. (2011). Taking children seriously: An alternative agenda for research? Journal of Early Childhood Research, 9(2), 137-149. doi: $10.1177 / 1476718 \times 10387897$

Burgess, S. (2002). Shared reading correlates of early reading skills. Reading online, 5(7), $\mathrm{n} 7$.

Burgess, S. R. (2010). Home literacy environments (HLEs) provided to very young children. Early Child Development and Care, 181(4), 445-462. doi: 10.1080/03004430903450384

Deckner, D. F., Adamson, L. B., \& Bakeman, R. (2006). Child and maternal contributions to shared reading: Effects on language and literacy development. Journal of applied developmental psychology, 27(1), 31-41.

Evans, M. A., Shaw, D., \& Bell, M. (2000). Home literacy activities and their influence on early literacy skills. Canadian Journal of Experimental Psychology/Revue canadienne de psychologie expérimentale, 54(2), 65.

Fisher, R. (2010). Young writers' construction of agency. Journal of Early Childhood Literacy, 10(4), 410-429. doi: 10.1177/1468798410382407

Johnson, A. D., Martin, A., Brooks-Gunn, J., \& Petrill, S. A. (2008). Order in the house! Associations among household chaos, the home literacy environment, maternal reading ability, and children's early reading. Merrill-Palmer quarterly (Wayne State University. Press), 54(4), 445.

Kenner, C., Ruby, M., Jessel, J., Gregory, E., \& Arju, T. (2007). intergenerational learning between children and grandparents in east London. Journal of Early Childhood Research, 5(3), 219-243. doi: 10.1177/1476718x07080471

Levy, B. A., Gong, Z., Hessels, S., Evans, M. A., \& Jared, D. (2006). Understanding print: Early reading development and the contributions of home literacy experiences. Journal of Experimental Child Psychology, 93(1), 63-93.

Melhuish, E. C., Phan, M. B., Sylva, K., Sammons, P., SirajBlatchford, I., \& Taggart, B. (2008). Effects of the home learning environment and preschool center experience upon literacy and numeracy development in early primary school. Journal of Social Issues, 64(1), 95-114.

Neumann, M. M. (2014). An examination of touch screen tablets and emergent literacy in Australian pre-school children. Australian Journal of Education, 58(2), 109-122. doi: 10.1177/0004944114523368

Neumann, M. M., Hood, M., \& Ford, R. M. (2013). Using environmental print to enhance emergent literacy and print motivation. Reading and Writing, 26(5), 23. doi: 10.1007/s11145-012-9390-7

Neumann, M. M., Hood, M., Ford, R. M., \& Neumann, D. L. (2012). The role of environmental print in emergent literacy. Journal of Early Childhood Literacy, 12(3), 231-258.

Park, H. (2008). Home literacy environments and children's reading performance: A comparative study of 25 countries. Educational Research and Evaluation, 14(6), 489-505.

Raikes, H., Alexander Pan, B., Luze, G., Tamis-LeMonda, C. S., Brooks-Gunn, J., Constantine, J., . . . Rodriguez, E. T. (2006). Mother-child bookreading in low-income families: Correlates and outcomes during the first three years of life. Child Development, 77(4), 924-953.

Roberts, J., Jurgens, J., \& Burchinal, M. (2005). The role of home literacy practices in preschool children's language and emergent literacy skills. Journal of Speech, Language and Hearing Research, 48(2), 345.

Roskos, K. A., Christie, J. F., Widman, S., \& Holding, A. (2010). Three decades in: Priming for meta-analysis in play-literacy research. Journal of Early Childhood Literacy, 10(1), 5596. doi: $10.1177 / 1468798409357580$

Sénéchal, M., \& LeFevre, J.-A. (2002). Parental Involvement in the Development of Children's Reading Skill: A Five-Year Longitudinal Study. Child Development, 73(2), 445-460. doi: 10.1111/1467-8624.00417

Stephenson, K. A., Parrila, R. K., Georgiou, G. K., \& Kirby, J. R. (2008). Effects of home literacy, parents' beliefs, and children's task-focused behavior on emergent literacy and word reading skills. Scientific Studies of Reading, 12(1), 2450.

Weigel, D. J., Martin, S. S., \& Bennett, K. K. (2006). Contributions of the home literacy environment to preschool-aged children's emerging literacy and language skills. Early Child Development and Care, 176(3-4), 357-378. doi: $10.1080 / 03004430500063747$.

Schneider, Benjamin, and S. S. White. 2004. Service Quality: Research Perspectives. London: Sage Publications, Inc.

Schultz, TW. 1960. Capital Formation by Education. The Journal of Political Economy Vol. 68, No. 6 (Dec., 1960), pp. 571-583.

Sherman, Stratford \& Freas, Alyssa. 2004. The Wild West of Executive Coaching. Harvard Business Review.

Spector, Paul E.( 2012). 6th Ed. Industrial and Organizational Psychology; Research and Practice. Singapore : John Wiley \& Sons. Inc.

Subramaniam,Mohan \&Youndt, Mark A. (2005). The influence of intellectual capital on the types of innovative capabilities. Academy of Management Journal. Doi: 10.5465/AMJ.2005.17407911, June 1, 2005 vol. 48 no. 3450 463.

Sulastiana, Marina,Anissa L.Kadiyono, Suryana Sumantri (2014). Pengaruh Human Capital Dan Servant Leadership Terhadap Iklim Pelayanan dan Dampaknya Pada Kinerja Pelayanan Publik. Bandung : PPM Fakultas Psikologi Unpad.

Utrilla, Pedro Nunez Cacho, Félix Angel Grande, Daniel Lorenzo. 2014. The effects of coaching in employees and organizational performance : The Spanish Case. Intangible Capital, 2015 - 11(2): 166-189 - Online ISSN: 1697-9818 Print ISSN: 2014-3214, http://dx.doi.org/ 10.3926/ic.586.

Wright, Patrick M \& Snell, Scott A.(1999). Understanding executive diversity: More than meets the eye. HR. Human Resource Planning; New York22.2 (1999): 49-51. 